Neurolmages

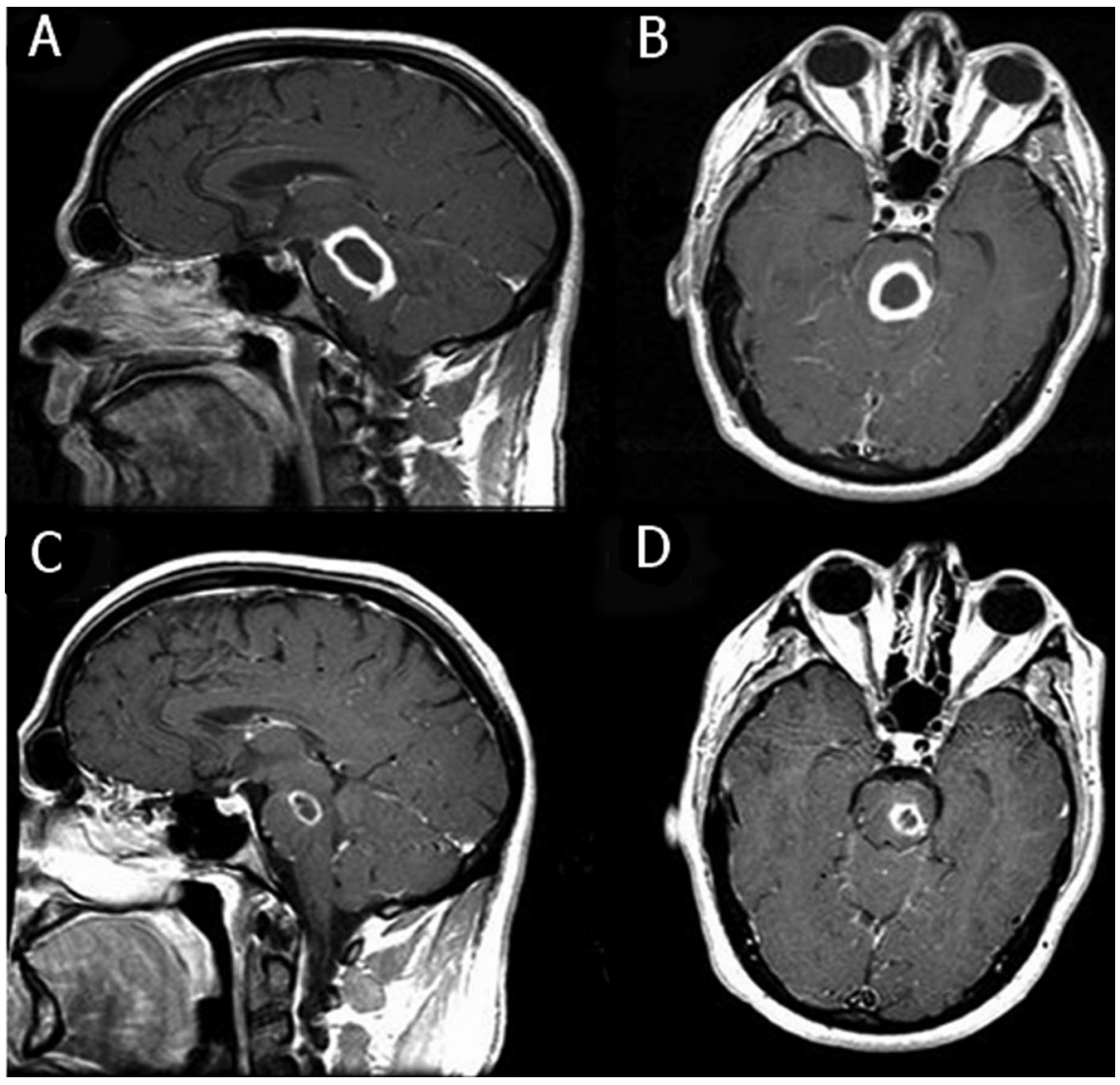

Figure. All panels are with gadolinium enhancement. (A) Parasagittal T1-weighted MRI of the brain showing a bacterial abscess in the dorsal pons. (B) Axial T1-weighted images of the same abscess. $(C, D)$ As per (A) and $(B)$ but after stereotactic needle aspiration.

\section{Solitary brainstem abscess}

Gary Sclar, MD; Peter Boardman, MD; and

Charles J. Prestigiacomo, MD, Brooklyn, NY (G.S.), and Newark, NJ (P.B., C.J.P.)

A 39-year-old man presented with a 2-day history of progressive right body numbness, left lateral rectus palsy, and ataxia Brain MRI revealed a possible abscess $(1 \mathrm{~cm} \times 1.1 \mathrm{~cm})$ in the left pons. Broad-spectrum antibiotics were started but after 4 days the patient became lethargic, with ptosis and hydrocephalus. The lesion had grown to $2.4 \times 3.4 \mathrm{~cm}$ (figure, A and B). A stereotactic needle biopsy was performed and $3 \mathrm{~mL}$ of pus aspirated. Cultures

Disclosure: The authors report no conflicts of interest.

Address correspondence and reprint requests to Dr. Gary Sclar, Asst. Prof., Dept. of Neurology, Long Island College Hospital, 339 Hicks St., Brooklyn, NY 11201-5509; e-mail: garysclar@yahoo.com revealed Streptococcus intermedius, a Gram-positive anaerobic bacteria. The patient received a 6 -week course of ceftriaxone and metronidazole. Residual symptoms and signs included severe right facial and moderate right body numbness; rapid end point horizontal nystagmus, most prominent on leftward gaze; a component of rotary nystagmus on upgaze; and jerky, dysmetric visual pursuits in the horizontal (but not vertical) plane. The patient's gait had a strong steppage quality but only on the right side; he was unable to attempt tandem walking.

Solitary brainstem abscesses account for only $0.5 \%$ of intracranial abscesses overall, the pons being the most common site. Few are successfully treated and a minority of these by stereotactic aspiration. ${ }^{1}$ Because of the small spaces involved, neurologic damage may progress rapidly. Aspiration seems to have been the turning point in this case.

1. Sarma S, Sekhar LN. Brain-stem abscess successfully treated by microsurgical drainage: a case report. Neurol Res 2001;23:855-861.

$\overline{\text { See also } 1230}$ 


\title{
Neurology
}

\author{
Solitary brainstem abscess \\ Gary Sclar, Peter Boardman and Charles J. Prestigiacomo \\ Neurology 2007;68;1231 \\ DOI 10.1212/01.wnl.0000261249.08291.26
}

This information is current as of April 9, 2007

\section{Updated Information \& Services}

References

Subspecialty Collections

Permissions \& Licensing

Reprints including high resolution figures, can be found at: http://n.neurology.org/content/68/15/1231.full

This article cites 1 articles, 0 of which you can access for free at: http://n.neurology.org/content/68/15/1231.full\#ref-list-1

This article, along with others on similar topics, appears in the following collection(s):

Abscess

http://n.neurology.org/cgi/collection/abscess

All Imaging

http://n.neurology.org/cgi/collection/all_imaging

All Infections

http://n.neurology.org/cgi/collection/all_infections

MRI

http://n.neurology.org/cgi/collection/mri

Information about reproducing this article in parts (figures,tables) or in its entirety can be found online at:

http://www.neurology.org/about/about_the_journal\#permissions

Information about ordering reprints can be found online:

http://n.neurology.org/subscribers/advertise

Neurology ${ }^{\circledR}$ is the official journal of the American Academy of Neurology. Published continuously since 1951, it is now a weekly with 48 issues per year. Copyright . All rights reserved. Print ISSN: 0028-3878. Online ISSN: 1526-632X.

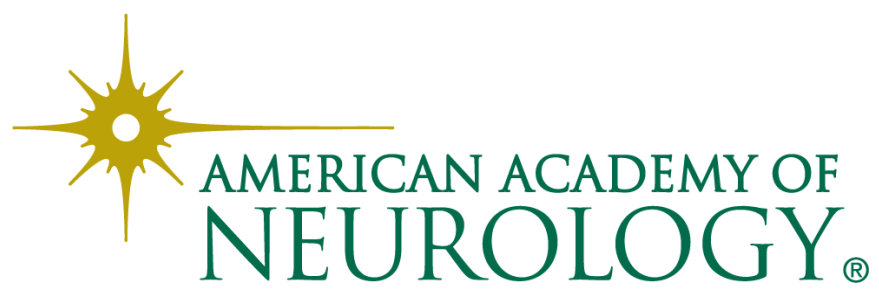

